COMECHINGONIA. REVISTA DE ARQUEOLOGÍA

Número 14, 2011, pp. 75-96, Córdoba

ISSN 0326-7911

\title{
POR ENCIMA DE LAS NUBES. CAMINOS, SANTUARIOS Y ARTE RUPESTRE EN LA SERRANÍA DE CALILEGUA (JUJUY, ARGENTINA).
}

\author{
Pablo Cruz ${ }^{1}$ y Rosario Jara ${ }^{2}$ \\ ${ }^{1}$ CONICET-FUndANDES. Parque Nacional Calilegua, San Lorenzo s/n, Calilegua, Jujuy. E-mail: \\ saxrapablo@gmail.com. \\ ${ }^{2}$ MLGSM-Parque Nacional Calilegua. San Lorenzo s/n, Calilegua, Jujuy. E-mail: rjara@apn.gov.ar
}

Presentado el: 5/10/2010 - Aceptado 24/03/2011

\section{Resumen}

Investigaciones desarrolladas en la serranía de Calilegua (Jujuy, Argentina) pusieron en evidencia una intensa ocupación de la región durante los períodos de Desarrollos Regionales e Inka. Esta se relaciona tanto con la explotación de yacimientos mineros como con la producción de recursos silvestres de alta valoración simbólica propios de la franja selvática de la vertiente oriental andina. En este trabajo se presentan y se analizan los nuevos datos registrados, focalizándonos en los sitios con arte rupestre y su participación en la demarcación simbólica del territorio y sacralización del espacio.

Palabras claves: Arte Rupestre, Vertiente Oriental Andina, Desarrollo Regionales, Inka.

\begin{abstract}
Researchs developed in the mountainous area of Calilegua (Jujuy, Argentina) revealed an intense occupation of the region during the Regional Developments and Inka periods. This is related as much to the mining deposits' operation as to the wild resources' production of high symbolic value of the Andean Eastern slope's sylvan strip. In this paper new registered data are presented and analyzed, focusing in rock art sites and their participation in the symbolic demarcation of the territory and in the sacralisation of the space.
\end{abstract}

Key Words: Rock art, Andean Eastern Slope, Desarrollos Regionales, Inka.

\section{Introducción}

Este trabajo persigue un doble objetivo. Por un lado presentar una síntesis de los resultados alcanzados en las investigaciones desarrolladas en la serranía de Calilegua (Jujuy), 
particularmente los nuevos registros de sitios con arte rupestre. Por el otro, analizar la intervención de estos sitios en la construcción y demarcación simbólica del territorio.

Concepto a la vez complejo y polisémico, entendemos por territorio tanto "al producto de la transformación del endosomático terrestre por el exosomático humano" siguiendo la formulación de Raffestin (1986:177), como a la apropiación social de un espacio mediante el agenciamiento de aquellos recursos económicos y simbólicos que estructuran las condiciones prácticas de la existencia de un colectivo auto-identificado con el mismo (Di Méo, 1991; Debarbieux, 1999). Este concepto es indisociable del de territorialidad, en tanto que estructura relacional y multidimensional establecida entre una sociedad y su territorio; ella comprende tanto la identidad con un espacio determinado, la exclusividad proclamada dentro de éste y los modos de interacción establecidos con el medio (Soja, 1971). Dentro de este marco, consideramos los sitios con arte rupestre, como también los santuarios, los caminos y las minas, como hitos espaciales cargados de sentidos, es decir como geo-símbolos. En palabras de Bonnemaison (1992:76), los geo-simbolos son "lugares", relieves, itinerarios, rutas, construcciones, sitios, etc. que, por razones religiosas, culturales o políticas, adoptan en los ojos de los grupos étnicos y sociales una dimensión simbólica que los arraiga en su identidad, y que por ende, participa activamente en la construcción territorial. Es en esta perspectiva territorial y geo-simbólica que creemos que las producciones visuales de los sitios con arte rupestre registrados expresan toda su capacidad agentiva, en tanto que sistemas de acción destinado a construir/cambiar el mundo más que meras manifestaciones expresivas (Gell, 1998).

Así, en tanto que hecho social total, y tal como los formulara Lefevbre (1976, 1981), cada dimención de un territorio resultan y reflejan de manera explícita, la complejidad de las relaciones sociales. En el estado incipiente de las investigaciones, nuestra intención es explorar aquí algunas de estas relaciones en torno a hitos territoriales que denotan una fuerte carga simbólica. Los sitios aquí presentados son el resultado de una primera fase de investigación llevada a cabo dentro del marco del Programa de Arqueología de la serranía de Calilegua. Ellos son el resultado de varias campañas de prospección y registro de sitios realizadas durante los años 2008 y 2010. La totalidad de los paneles con arte rupestre registrados fueron integralmente fotografiados utilizando escalas y cuadrantes, y, posteriormente, recompuestos y calcados digitalmente.

\section{La región: ambiente y fuentes documentales}

La serranía de Calilegua se localiza en los departamentos Valle Grande y Ledesma de la provincia de Jujuy, en el extremo norte de la Argentina. La serranía se inserta en la provincia geológica de las sierras subandinas, el primer cordón montañoso andino después de la extensa llanura chaqueña. Ellas constituyen una barrera orográfica que cautiva los vientos húmedos del Atlántico dando lugar a una franja selvática denominada comúnmente "Yungas". El relieve de la serranía, dominado por los cerros Amarillo (3.600 m) y Hermoso (3.500 m.), alterna cumbres, mesetas de altura y estrechos valles. Las Yungas, o selva tucumano-boliviana, se identifican por su notable biodiversidad, tanto por su riqueza de especies como por el número de endemismos. Cuatro pisos ecológicos se demarcan en función de la gradiente altitudinal (Cabrera 1976; Brown y Kapelle 2001). (1) La selva pedemontana se extiende desde los $400 \mathrm{~m}$ hasta los $700 \mathrm{~m}$ y se individualiza por sus bosques tropicales, sobresaliendo las especies de palo blanco (Calycophyllum multiflorum), palo amarillo 
(Phyllostylon rhamnoides), lapacho rosado (Tabebuia impetiginosa), cedro rosado (Cedrela balansae), roble (Amburana cearensis), cebil colorado (Anadenanthera colubrina), entre otros. (2) Este piso es seguido por la selva montana caracterizada por laderas, entre los $700 \mathrm{~m}$ y 1.500 $\mathrm{m}$, que reciben un máximo de precipitaciones pluviales. Las especies dominantes son de origen tropical, entre ellas el laurel del monte (Phoebe porphyria), el cebil (Anadenanthera macrocarpa) y la tipa (Tipuana tipu). Por encima de este nivel, entre los $1.500 \mathrm{~m}$ y $3.000 \mathrm{~m}$, se sitúan (3) los bosques montanos, llamados también "bosques nublados", cuyo escarpado relieve se encuentra poblado por pinos del cerro (Podocarpus parlatorei), alisos (Alnus acuminata), nogales (Juglans australis), y queñoa (Polylepis australis), entre los más representativos. Finalmente, por encima de los $3.000 \mathrm{~m}$ yacen (4) los pastizales de neblina caracterizados por pajonales de gramíneas de los géneros Festuca, Calamagrostis y Stipa.

En cuanto a las informaciones históricas sobre los antiguos pobladores de la región, varios documentos del siglo XVI ${ }^{1}$ señalan que las serranías situadas al "este" de la Quebrada de Humahuaca, por su correspondencia las serranías de Calilegua y Centa, estuvieron ocupadas antes del arribo de los españoles por un grupo étnico denominado "ocloya". Basados en estas fuentes, investigadores como Boman (1908), y más tarde Canals Frau (1953) y Vergara (1966) identificaron a los ocloyas como un grupo local sometido a sus vecinos inmediatos: los omaguacas quebradeños. Sin embargo, otras fuentes coloniales, como Sotelo de Narváez (1965 [1552]) $)^{2}$ remarcaron una filiación "andina" de los ocloyas, vinculada con los chichas y el sur de Bolivia, una pista que fue explorada por Lorandi (1980) y Sánchez y Sica (1990:478). En una síntesis que recoge las diferentes versiones, recientemente Ventura (2007: 117) sugirió que los ocloyas se habrían finalmente sometidos a los omaguacas sólo después del derrumbe del Tawantinsuyu. Por su parte, y en acuerdo con lo vertido por Ventura, los nuevos registros de la serranía de Calilegua reafirman la ocupación inkaica del territorio. Desde esta perspectiva, y sin poder responder a la pregunta sobre su procedencia, es posible que los ocloyas citados por las fuentes hayan sido mitmackunas que acompañaron la expansión meridional del Tawantinsuyu. Con sus particularidades ecológicas e históricas, este territorio se habría integrado a comienzos de la Colonia dentro de un espacio más amplio, el cual incluía, de manera general, el conjunto de sierras y valles de la vertiente oriental andina (Iruya, Cimarrones, Valle Grande, Centa), así como la ceja de selva.

\section{La carta arqueológica y la ocupación durante los períodos de Desarrollos Regionales e Inka}

Las prospecciones llevadas a cabo permitieron registrar a la fecha 42 sitios arqueológicos, 15 de ellos afiliados al Período Formativo y los 27 restantes a los períodos de Desarrollos Regionales e Inka, en distintos sectores de la serranía de Calilegua, de la cuenca del río Valle Grande y de las laderas pedemontanas (Figura 1). No obstante, es importante señalar el carácter parcial del registro, el cual se encuentra principalmente limitado por la densa cobertura vegetal, los intensos procesos de formación de suelos detríticos y el relieve abrupto de la serranía. En su mayoría, los sitios afiliados al Período Formativo se localizan sobre las planicies pedemontanas, en cercanía de ríos o vertientes permanentes, y, en menor medida, en el interior de la serranía y en las mesetas de altura. De manera general, la cerámica hallada en la superficie de estos sitios se inscribe dentro de los estilos conocidos para el complejo San Francisco (Dougherty 1974, 1977; Kulemeyer y Echenique 2002, Kulemeyer et al. 1997; Ortiz 1998, 2000, 2002). Por su parte, los sitios arqueológicos afiliados a los períodos de Desarrollos Regionales e Inka se encuentran todos ellos situados al interior de la serranía, 


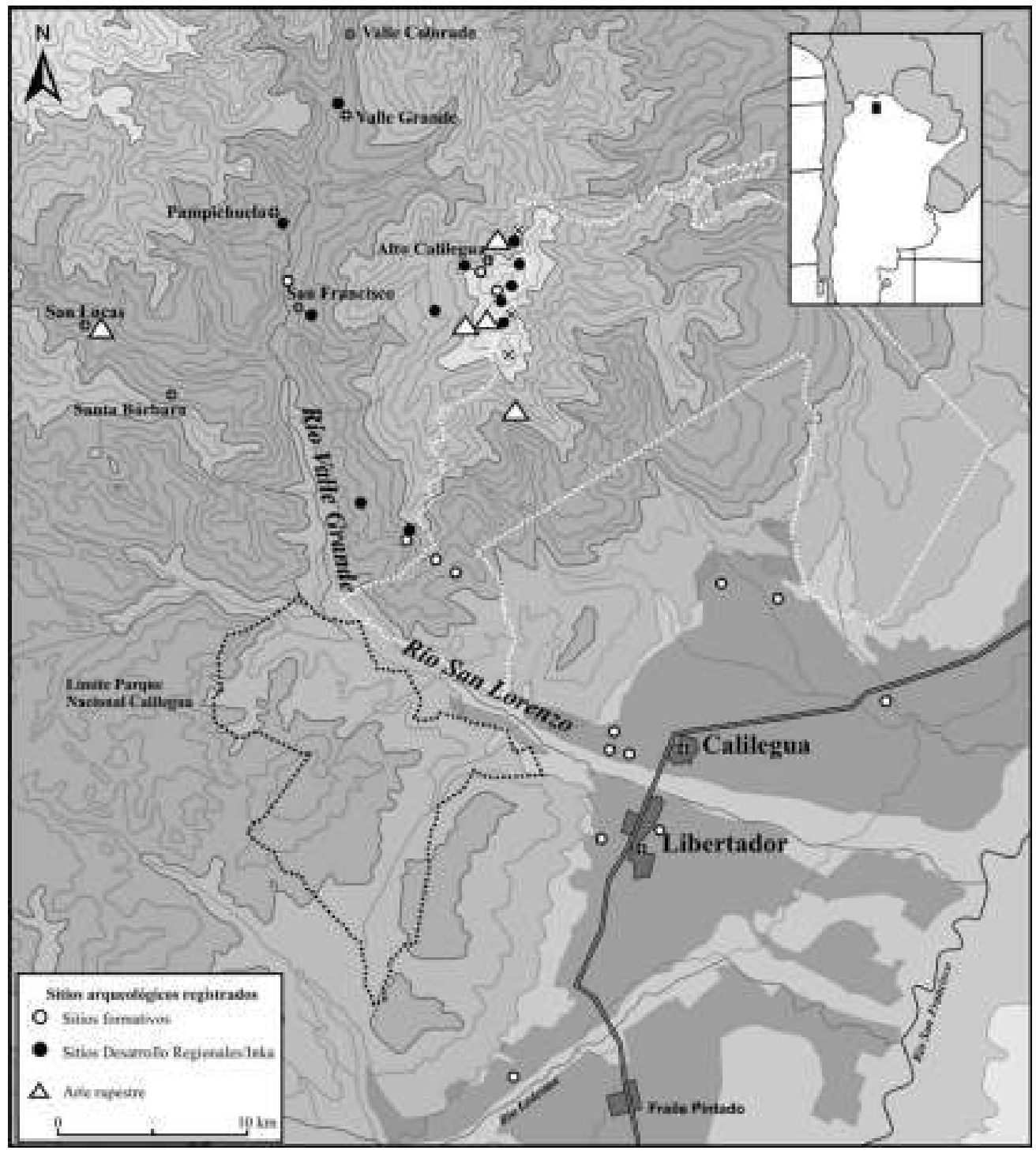

Figura 1. Mapa del área de estudio y localización de sitios arqueológicos registrados.

tanto en las mesetas medianas y de altura (entre los $1.000 \mathrm{~m}$ y $1.500 \mathrm{~m}$ ), como en las laderas cercanas al río Valle Grande. Los sitios tardíos registrados dejan ver por lo menos tres niveles de establecimiento: (1) aglomeraciones medianas sobre las mesetas serranas: San Francisco, Pampichuela, Valle Grande y Potrero; (2) establecimientos reducidos sobre las laderas selváticas y sobre las mesetas de altura: sitios Horco Quebracho, Pueblito, Duraznillo; e (3) instalaciones reducidas y temporales sobre las cumbres de la serranía de Calilegua. Las aglomeraciones medianas son aquellos sitios de habitación de una superficie comprendida entre 0.50 y $1 \mathrm{Ha}$, a juzgar por las dispersión de materiales y los escasos restos de muros observados. En cuanto a los establecimientos reducidos, se trata igualmente de sitios de habitación asociados directamente con áreas de producción agrícola o minera. Finalmente, 
las instalaciones reducidas identifican conjuntos de estructuras aisladas (estructuras de habitación y recintos).

Tal como lo señalaran anteriormente varios autores, el material cerámico observado en la superficie de estos sitios muestra claras vinculaciones con la quebrada de Humahuaca, sobresaliendo los estilos negro sobre rojo, Angosto Chico inciso y Angosto Chico corrugado 3 . Los primeros estilos fueron fechados en la Quebrada de Humahuaca a partir del 1.280 d.C. (Nielsen, 1997), mientras que las vasijas corrugadas Angosto Chico se asocian directamente con la fase inkaica (Cremonte 2006:41). Los nuevos datos arqueológicos señalan que el establecimiento de los inkas en la región se relaciona con la explotación de yacimientos mineros y recursos de alta valoración simbólica (Cruz, 2010a). Su presencia se evidencia tanto en la ocupación de sitios de habitación locales, como en la implantación de enclaves productivos, en la adecuación de una red de senderos y caminos, en la construcción de santuarios sobre la cumbre de los cerros, y en los sitios con arte rupestre. En cuanto a los recursos económicos y simbólicos ${ }^{4}$ disponibles en la región, se destacan por su accesibilidad los vegetales enteógenos con propiedades narcóticas y psicoactivas (cebil, complejo ayahuasca, psicotria, coca silvestre, tabaco, entre las más importantes), así como las pieles y cueros (15 especies), plumas ( 48 especies) y maderas (38 especies) (Cruz, 2010a). Relacionado con la explotación de estos recursos, en el paraje denominado Horco Quebracho, localizado en cercanías del río Valle Grande, se puso en evidencia un establecimiento productivo, conformado por dos conjuntos habitacionales distanciados entre sí por $50 \mathrm{~m}$. El primer conjunto comporta un número de tres unidades habitacionales de planta circular (entre $4 \mathrm{~m}$ y $4.5 \mathrm{~m}$ ). Sondeos de verificación efectuados al interior y exterior de uno de estos recintos permitieron obtener una significativa muestra de material cerámico, el cual muestra estilos afiliados a los Desarrollos Regionales e Inka. El segundo sector comporta un número de 13 unidades habitacionales, dispuestas de manera alineada sobre un barranco, de planta circular, de dimensiones semejantes a las anteriores (Figura 2). Sin embargo, los sondeos de verificación realizados en varias de estas unidades dieron como resultado una significativa ausencia de restos materiales. Por otro lado, asociado con este sitio, se registraron, superficies de producción agrícolas con sistemas de drenajes sobre laderas de pendientes pronunciadas. El relieve abrupto, el sistema de drenaje, la variable altitudinal $(1.100 \mathrm{msnm})$ y el medio tropical y selvático donde se encuentran estas superficies de producción sugieren que estaban destinadas al cultivo de variedades domésticas de coca, pista en la cual se está investigando. Asimismo, es importante señalar que algunas fuentes se refieren a la existencia de cocales en la región "que nadie ignora el comercio que con ambos [junto al "palo de tinte"] se hace en estas provincias" (Fernández Cornejo, 1837) y que cultivos experimentales de coca doméstica fueron desarrollados con éxito en Calilegua hace pocos años atrás (INTA, Salta, 2004). Pero más allá de la especie cultivada, el conjunto de evidencias sugiere que se trata de una colonia productiva, posiblemente con una población variable y estacional en función de los períodos de trasplante, limpieza y cosecha. En este sentido, se maneja junto con la hipótesis de cultivos de variedades domésticas de coca, que el conjunto de tres unidades habitacionales, con mayor evidencia de una ocupación estable que el otro conjunto, estaría relacionado con el control o la protección de la producción, algo semejante a lo sucedido con los cocamayocs inkaicos -en su mayoría mitmackunas-, referenciados por varias fuentes coloniales (p.e. la Visita de Pocona). Por otro lado, y tal como fue igualmente señalado en la documentación colonial, las prospecciones en la serranía permitieron registrar una acotada, pero intensa, área de explotación minera en el cerro Fundición (Cruz, 2010a). Asimismo, existen detalladas 


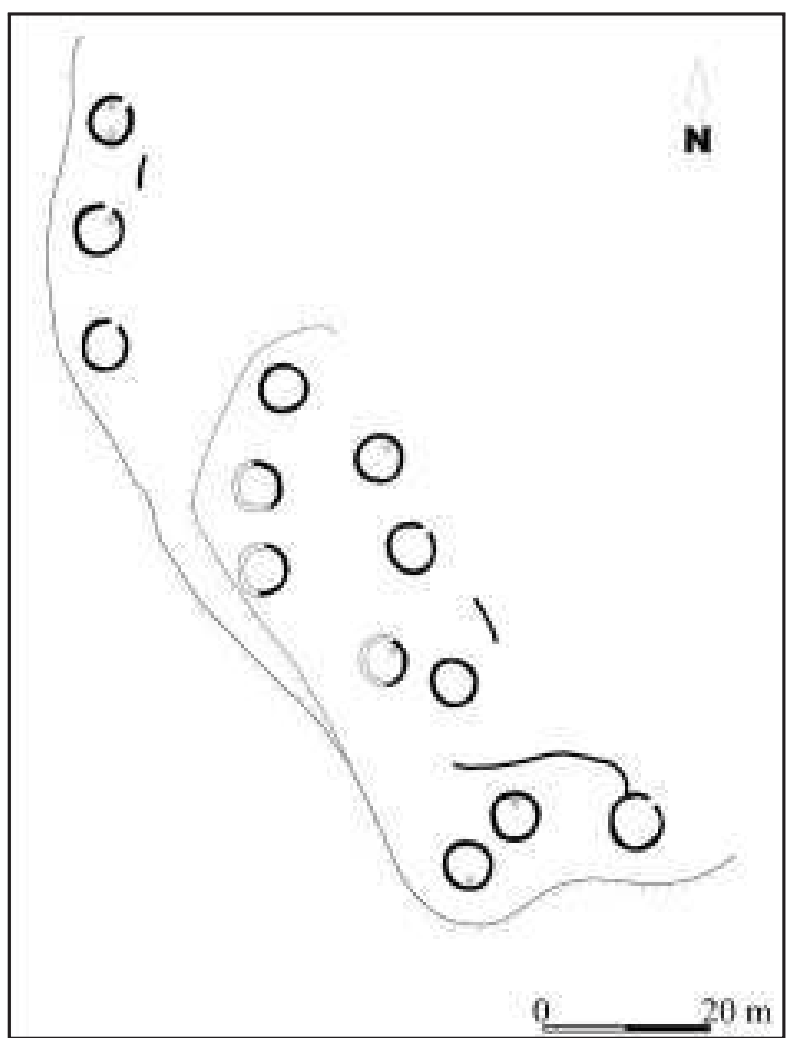

Figura 2. Sitio Horco Quebracho, conjunto de recintos, sector B.

informaciones catastrales sobre otros yacimientos mineros en varios sectores de la serranía de Calilegua, cuya antigüedad prehispánica queda todavía por resolver.

Prospecciones realizadas en 2009 y 2010 permitieron registrar un sector con explotaciones mineras prehispánicas en el cerro Fundición. No muy distante de estas antiguas minas se registraron igualmente algunas estructuras mineralúrgicas destinadas principalmente a la preparación de la mena (trituración y tostado de minerales). En esta perspectiva, creemos que el establecimiento inka conocido como "Pueblito", localizado al pie del cerro Amarillo anteriormente interpretado como un puesto fronterizo de avanzada (Raffino, 1993)-, se encontraría mas bien directamente vinculado con la explotación de yacimientos mineros y con la producción de metales. Y en efecto, un camino prehispánico vincula este sitio -y el complejo de plataformas del santuario del cerro Amarillo-, directamente con las minas registradas en el cerro Fundición. En cuanto a los santuarios de altura ${ }^{5}$, a parte del conocido santuario del Cerro Amarillo publicado por Raffino (1993), compuesto por un conjunto de siete plataformas (Figura 3), se registró otro santuario sobre la cumbre del cerro Hermoso, el cual dista unos $4 \mathrm{~km}$ del anterior. Éste se compone de un recinto rectangular, con muros a doble paramento en piedra, sobre la cumbre misma, y por tres conjuntos habitacionales localizados en la base del cerro, cada uno de ellos integrado por un número variable de recintos sub-circulares construidos con muros de piedra simple. 


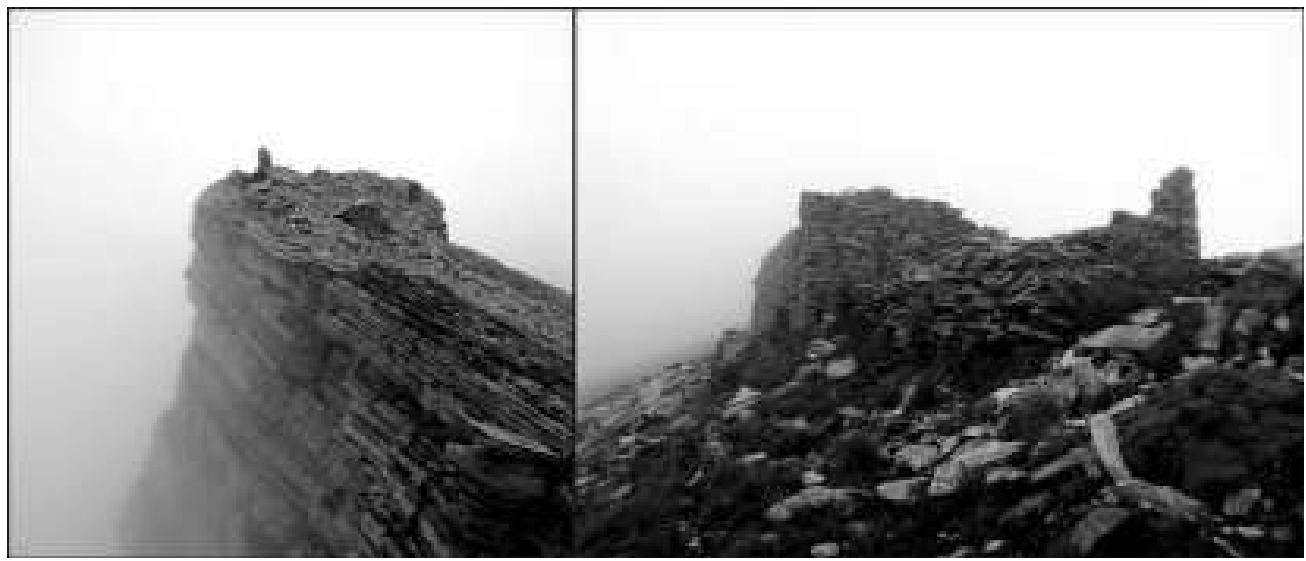

Figura 3. Fotografía del santuario inka del Cerro Amarillo.

Estos sitios e instalaciones se encuentran integrados entre sí al localizarse, todos ellos, en cercanías de senderos y caminos (sensu Berenguer, 2004b) ${ }^{6}$, que en su totalidad presentan segmentos y escalinatas empedradas (Figura 4). A parte del citado camino que vincula las minas del cerro Fundición con el sitio Pueblito y el santuario del cerro Amarillo, fueron
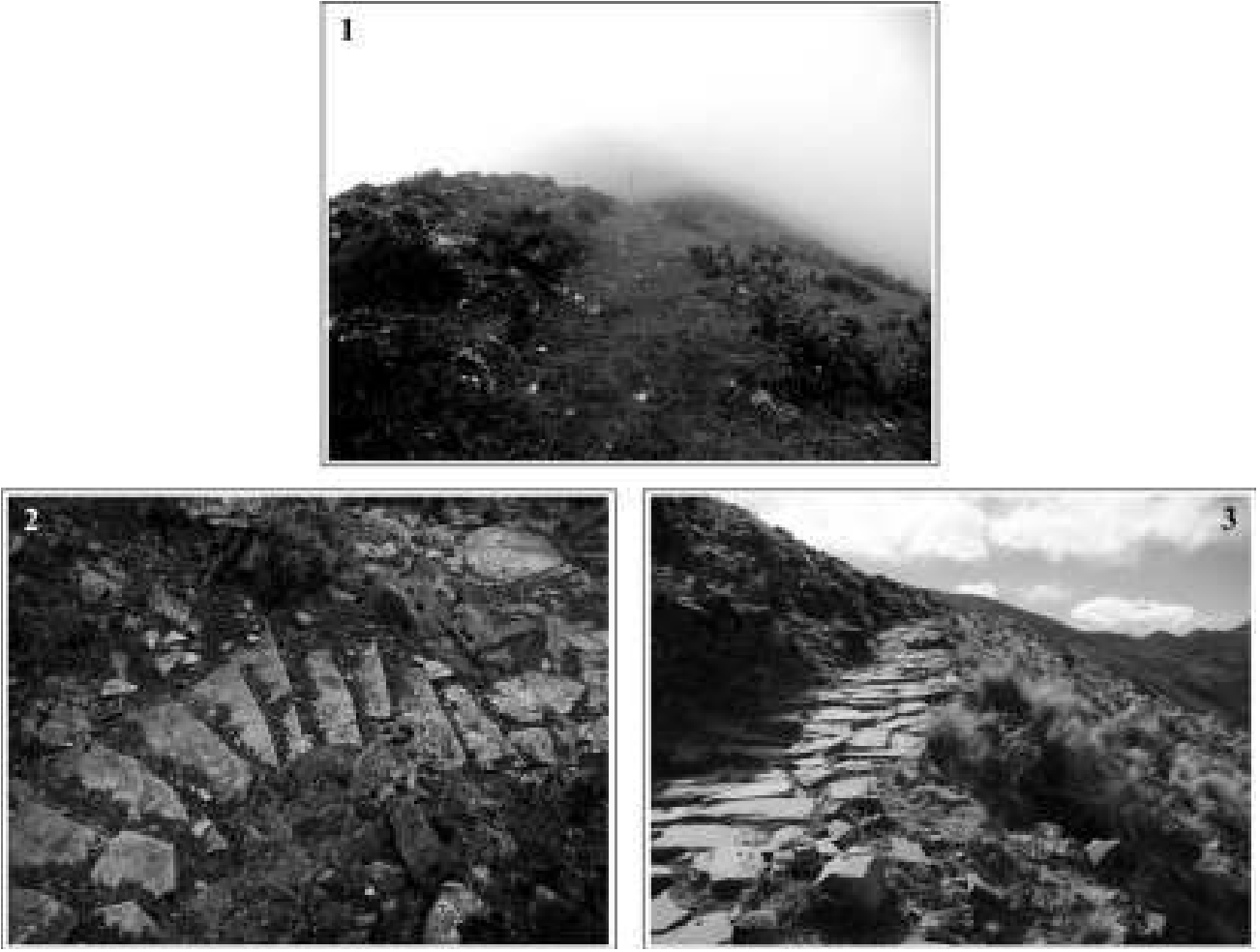

Figura 4. Fotografías de caminos inkaicos en el área de estudio. 1. Cerro Amarillo-PueblitoCerro Fundición. 2. Segmento empedrado de Despensa. 3. Tramo del Qhapaq Nan en Santa Ana. 
identificadas otras vías en los parajes denominados Duraznillo, Mesilla y Despensa, comunicando el piso de pastizales de neblina con los bosques y selvas pedemontanas. En su trayecto, estás vías entrelazan sitios de habitación (p.e. Alto Calilegua), establecimientos reducidos (entre 2 y 5 estructuras de habitación) y conjuntos de recintos. Asimismo, esta red de caminos que recorre y articula la serranía de Calilegua, estaría a su vez conectada al norte con el paso del Qhapaq Ñan cuyo trayecto es más evidente en la localidad de Santa Ana. En su recorrido por la cuenca del río Valle Grande, se trataría de un corredor natural orientado en sentido norte-sur que enlazaría los principales sitios de habitación registrados (San Francisco, Pampichuela, Valle Grande). También, a lo menos dos corredores naturales -utilizados hasta hace pocas décadas atrás-, comunican directamente con la Quebrada de Humahuaca (localidades de Tilcara y Humahuaca respectivamente). Es en cercanía de uno de estos caminos que se sitúa la cueva de San Lucas (Fernández Distel, 1988, 1992) en la localidad del mismo nombre. De esta manera, se trataría de una red vial estructurada en torno a tres niveles interrelacionados entre sí. Por un lado corredores intermontanos y extralocales que retoman grandes pasos naturales: uno al norte que enlaza con el Qhapaq Ñan de Santa Ana, y por lo menos dos que comunican, en un sentido este-oeste, con la quebrada de Humahuaca. Por otro lado, un tramado de caminos menores y senderos que articulan la cumbre de la serranía de Calilegua con la cuenca del río Valle Grande al oeste y con la ladera pedemontana -y más allá las planicies chaqueñas-, al este. Finalmente, varios caminos y senderos sobre la cumbre de la serranía enlazan sitios de habitación (p.e. Alto Calilegua, Pueblito), conjuntos de recintos y sectores mineros. Es en cercanía de estos últimos caminos y senderos que fueron registrados los sitios con arte rupestre que trataremos a continuación.

\section{El arte rupestre en la serranía de Calilegua}

A la fecha, tres nuevos sitios con arte rupestre fueron registrados en la serranía de Calilegua, los cuales se suman al ya conocido alero situado en la localidad de San Lucas. Estos sitios comportan un número variable entre uno y tres aleros rocosos con evidencias de arte rupestre, todos ellos localizados en proximidad de cursos secundarios y antiguos caminos. A continuación, presentaremos las características más resaltantes de los sitios registrados en Calilegua.

\section{Sitio Duraznillo (Figuras 5 y 6 )}

Localizado en el paraje homónimo, el sitio comprende un conjunto de tres aleros con arte rupestre. Estos se encuentran diseminados en una quebrada que corre por debajo del filo occidental de la serranía y que comunica, por el este y el sur con antiguos senderos que descienden hacia las planicies orientales. Uno de estos tres aleros se demarca por la cantidad, contenido y temporalidades de sus imágenes. Sin llegar por lo tanto a constituir paneles temáticos, tres espacios se individualizan en este alero: A) un espacio central, en el cual se concentran los diseños pintados; B) una roca desprendida de esta pared con una serie de grabados, y C), otro alero que muestra rastros desvanecidos de diseños pintados. En razón del estado de conservación y visibilidad de los diseños, nos referiremos aquí sobre los dos primeros espacios.

Sector A) En este espacio se identificaron 45 motivos pintados, de los cuales 33 son figurativos y 12 abstractos, varios de ellos superpuestos, correspondientes según su contenido iconográfico a tres períodos crono-culturales: prehispánico, colonial y sub-actual. Entre los 


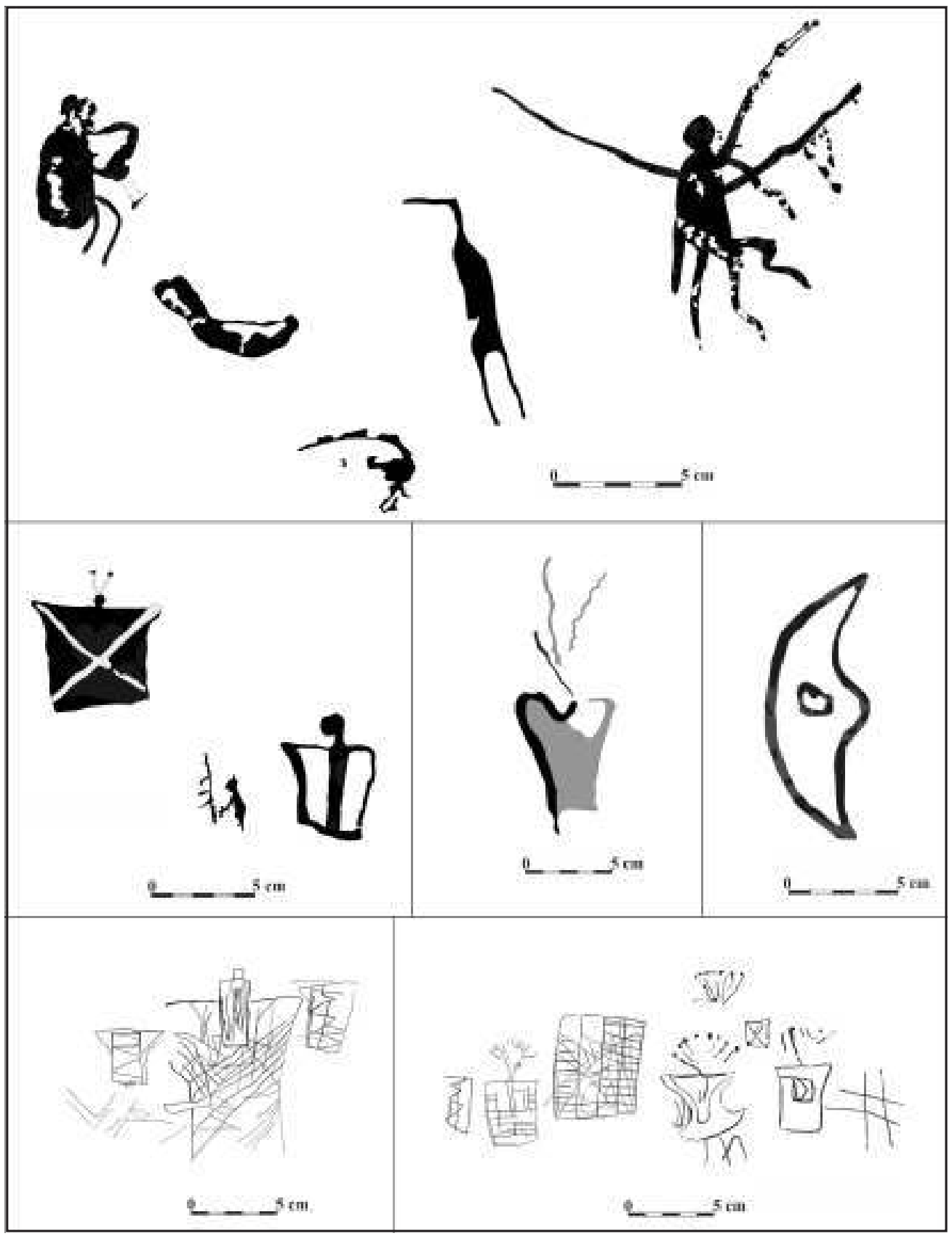

Figura 5. Pinturas y grabados rupestres del Alero de Duraznillo. 


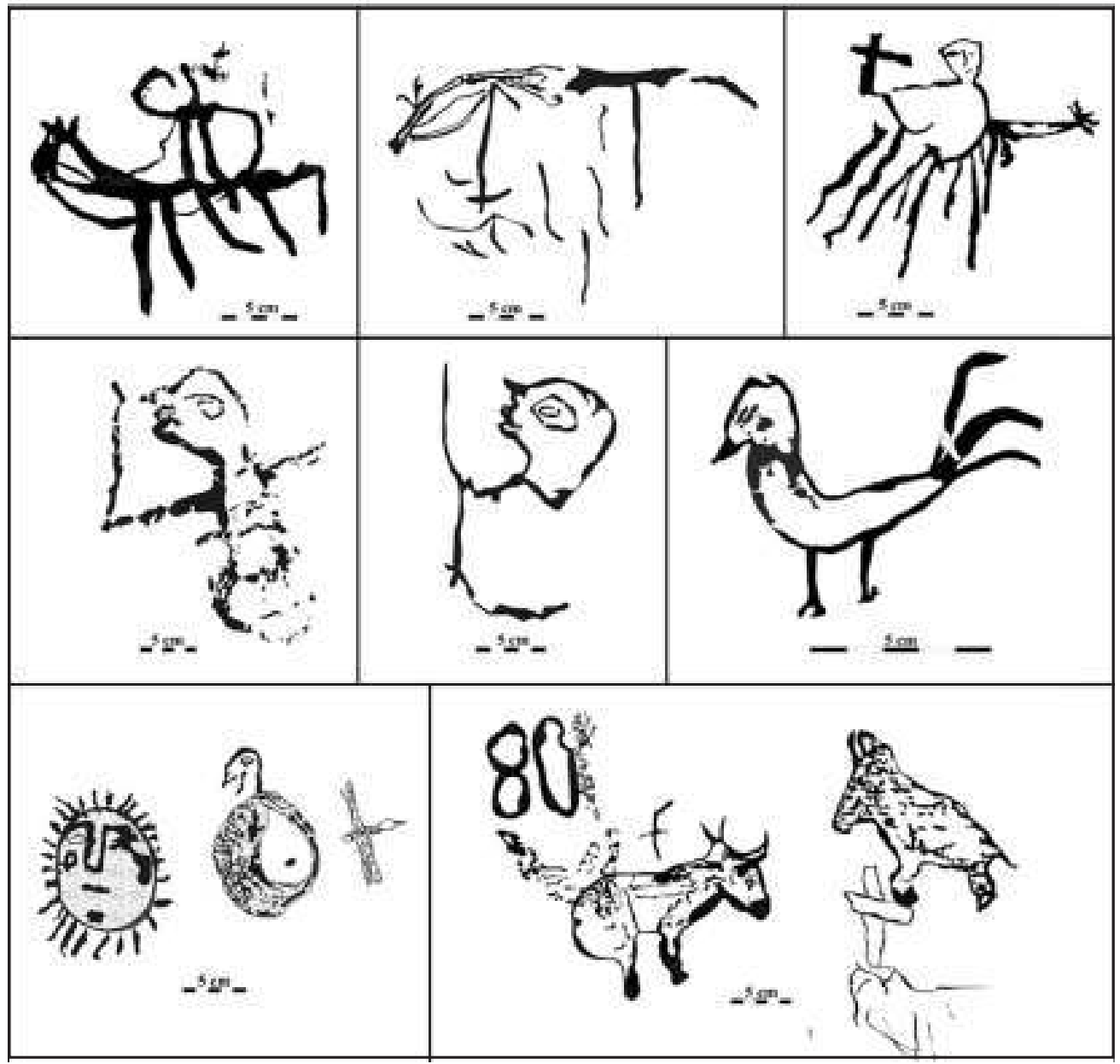

Figura 6. Pinturas rupestres coloniales y sub-actuales del Alero de Duraznillo.

motivos prehispánicos, se destacan diferentes tipos de figuras antropomorfas, tres de ellos portando atuendos realizado en dos colores (negro-rojo, negro-ante), uno de ellos presentando un diseño interno en doble diagonal. Este último diseño de atuendo fue relacionado con la presencia inkaica en el norte de Chile (Berenguer, 1999, 2004a y b). Asimismo, entre las imágenes zoomorfas se encuentran dos probables representaciones de cérvidos, una de ellas en rojo y la otra en negro, camélidos estilizados en negro, un reptil en negro y varias pisadas de aves. Entre los motivos figurativos se resalta una representación tumiforme y varios diseños abstractos semejantes a soles. Por su parte, entre los diseños coloniales encontramos la representación de un cura portando una cruz en su mano (negro), la de un jinete parado sobre un caballo (negro) y varias figuras ornitomorfas y antropo-ornitomorfas realizadas en negro y amarillo. Finalmente, las representaciones republicanas y sub-actuales, sino las más numerosas, las más evidentes, muestran bueyes, jinetes, caballos, soles, lunas e incluso una luna posteriormente trasfigurada en símbolo del ying-yang, todas ellas realizadas con trazos negros. 


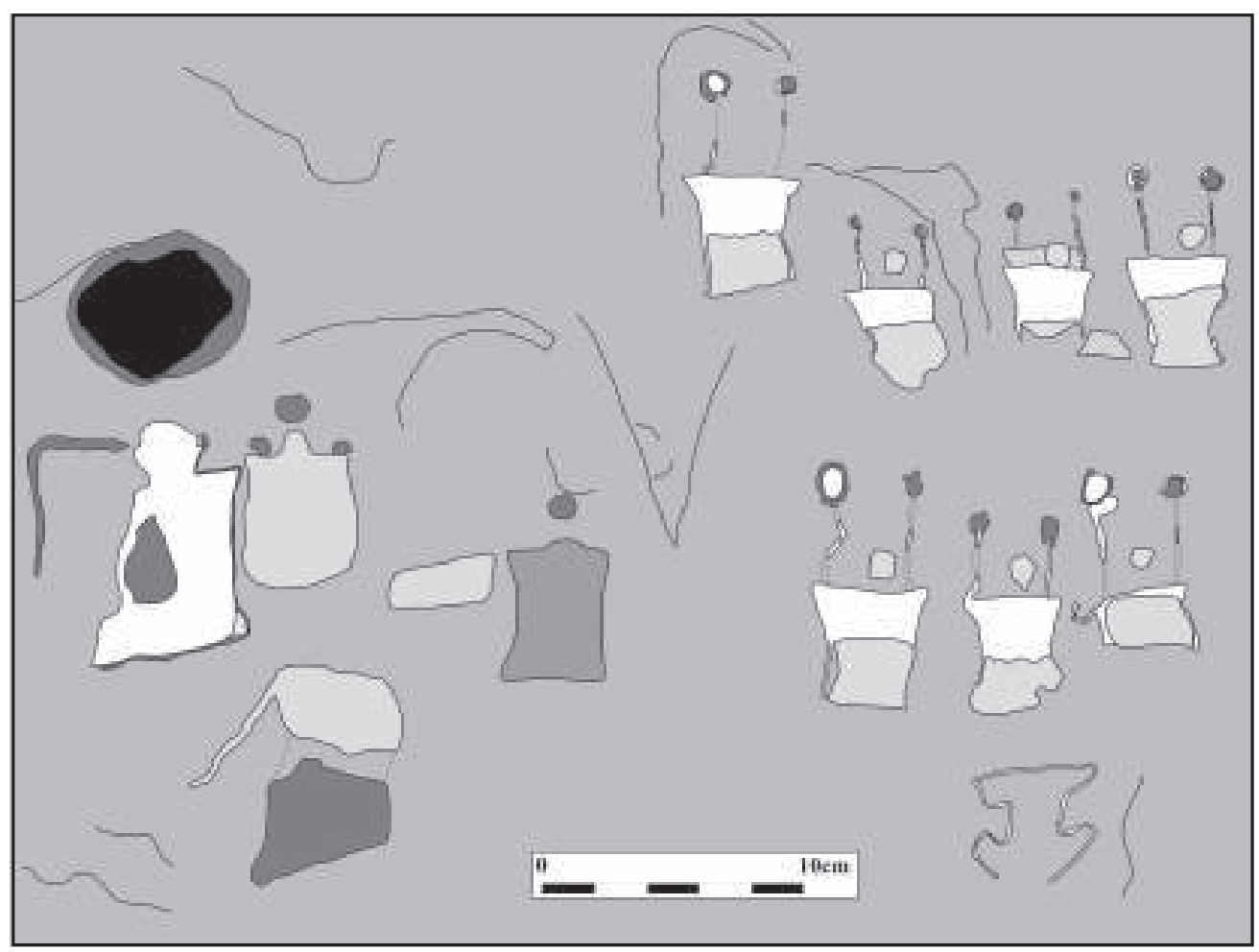

Figura 7. Pinturas rupestres del Alero del Mesilla.

Sector B) Prácticamente imperceptibles, se trata de un conjunto de 18 grabados concentrados sobre una de las caras de una roca desprendida de la pared. Es importante señalar, y puede ser significativo, el hecho que se trate, más que grabados, de un conjunto de motivos esgrafiados, todas ellos muy diminutos, y ejecutados con trazos imprecisos. En su mayoría, se trata de figuras antropomorfas portando atuendos, algunas de ellas con forma de $u n k u$, otras con atavío de tipo escutiforme (ver supra), y otras con penacho, acompañadas por diseños abstractos.

Finalmente, a escasos metros de este alero se encuentran otros aleros igualmente ornados con arte rupestre; aunque con imágenes poco visibles. Entre los motivos visibles, ocho diseños abstractos lineales pintados en negro, un diseño ramiforme y un figurativo que representa un cérvido en color negro, a juzgar por su morfología una "taruca" (Hippocamelus antisensis), la cual muestra trazos en su parte inferior que sugieren una herida.

\section{Sitio Mesilla (Figura 7)}

Este sitio comprende un conjunto de tres aleros localizados sobre una mesada de altura de la vertiente oriental de la serranía. En dos de estos aleros se observaron rastros de pinturas rupestres, aunque no se logró individualizar representación alguna dado el mal estado de conservación de los soportes. En el alero restante se identificó un panel en el cual se encuentran un conjunto de 11 figuras antropomorfas, de diferentes tamaños y morfologías, pintadas en 
blanco, ocre, amarillo y negro. Se destacan en este panel un grupo de siete personajes antropomorfos, los cuales portan atuendos (unkus), en color blanco y amarillo, y dos apéndices a modo de banderines. Inmediatamente por debajo de este grupo, se encuentra una figura de escutiforme, en color blanco, cuyo trazo parece estar incompleto. En otros espacios de este mismo alero se identificó otra representación antropomorfa con atuendo con líneas cruzadas en color negro, semejante a las observadas en Duraznillo, así como una llama estilizada en este mismo color. Finalmente, se destacan en este alero varios diseños de cruces del tipo potenzada o potente ${ }^{7}$ en amarillo, blanco y negro.

\section{Sitio Alero del Fundición (Figura 8)}

El alero se encuentra localizado en una estrecha quebrada al pie de los cerros Fundición y Amarillo, en un contexto general asociado con actividades mineras, y, probablemente, metalúrgicas (Cruz, 2010a). El alero presenta dos paneles bien definidos, uno con cuatro cruces grabadas coloniales y republicanas, y otro con un conjunto de nueve grabados prehispánicos, de los cuales ocho son de diseño geométrico y uno antropomorfo y esquematizado, el cual porta una lanza. Acompañan estos grabados, la representación estilizada de un camélido, en color negro. El diseño de tres de los grabados geométricos sugiere que se tratan de representaciones esquemáticas de atuendos, semejantes a los unkus señalados anteriormente. Entre los restantes se destacan dos con diseño ancoriforme, el cual, por sus semejanzas morfológicamente, puede relacionarse con ciertos pectorales y diademas metálicas, o bien, con los bancos de las autoridades andinas ${ }^{8}$. Se trata de un diseño que se presenta igualmente en otros sitios con arte rupestre del norte argentino y de Chile relacionado con los inkas (Núñez et al., 1997; Fernández Distel, 2004; Adris, 2007). Significativamente, en el sitio Quebrada de los Tambores-2 (San Pedro de Atacama), este diseño se encuentra asociado con tres figuras antropomorfas, una de las cuales porta un pectoral de forma semejante (Núñez et al. 1997:317). Diademas con formas cercanas a este diseño fueron dibujadas por Guaman Poma y Murúa y asociadas con la élite colla, y en particular con la figura del sacerdote principal del Tawantinsuyu: Willak Umu. Tal relación puede encontrar sentido si tenemos en cuenta, por un lado, el contexto de producción minera (minas del cerro Fundición) y religioso (santuarios de los cerros Amarillo y Hermoso) donde se enmarca este sitio, como las informaciones documentales que cuentan el rol preponderante que tuvo Willak Umu junto a Paullu Inka en las negociaciones de poder que siguieron los primeros años del contacto con los españoles, y que tuvieron a las minas como principal escenario de disputa.

De manera general y desde el punto de vista iconográfico, el arte rupestre prehispánico de la serranía de Calilegua, principalmente adscrito a los períodos de Desarrollos Regionales e Inka, parece relacionarse tanto con la Quebrada de Humahuaca (entre otros: Hernández Llosa, 1992; Nielsen et al., 2001), la puna jujeña (Ruiz et. al, 2001; Fernández Distel, 2004), y en menos medida con el norte de Chile (Núñez et al., 1997; Berenguer, 1999, 2004 a y b; Pimentel y Montt, 2008, 2009). No resultaría lo mismo con otras regiones vecinas, como ser la vertiente oriental andina en el sur de Bolivia, las planicies orientales y la región valliserrana del noroeste argentino. Nos referimos principalmente a los diseños antropomorfos identificados como "escutiformes" $\mathrm{u}$ hombres-hacha ${ }^{10}$, a las representaciones de atuendos, a las escenas que representan personajes alineados, en el caso del sitio Mesilla portando atuendos rectangulares, penachos y banderines, como también a los motivos que pueden ser interpretados como diademas o bancos de autoridades. En cuanto a las representaciones esquematizadas de llamas, imágenes igualmente asociadas con los inkas, los escasos registrosy la ausencia de escenas de caravanas, nos impide pronunciarnos certeramente. 


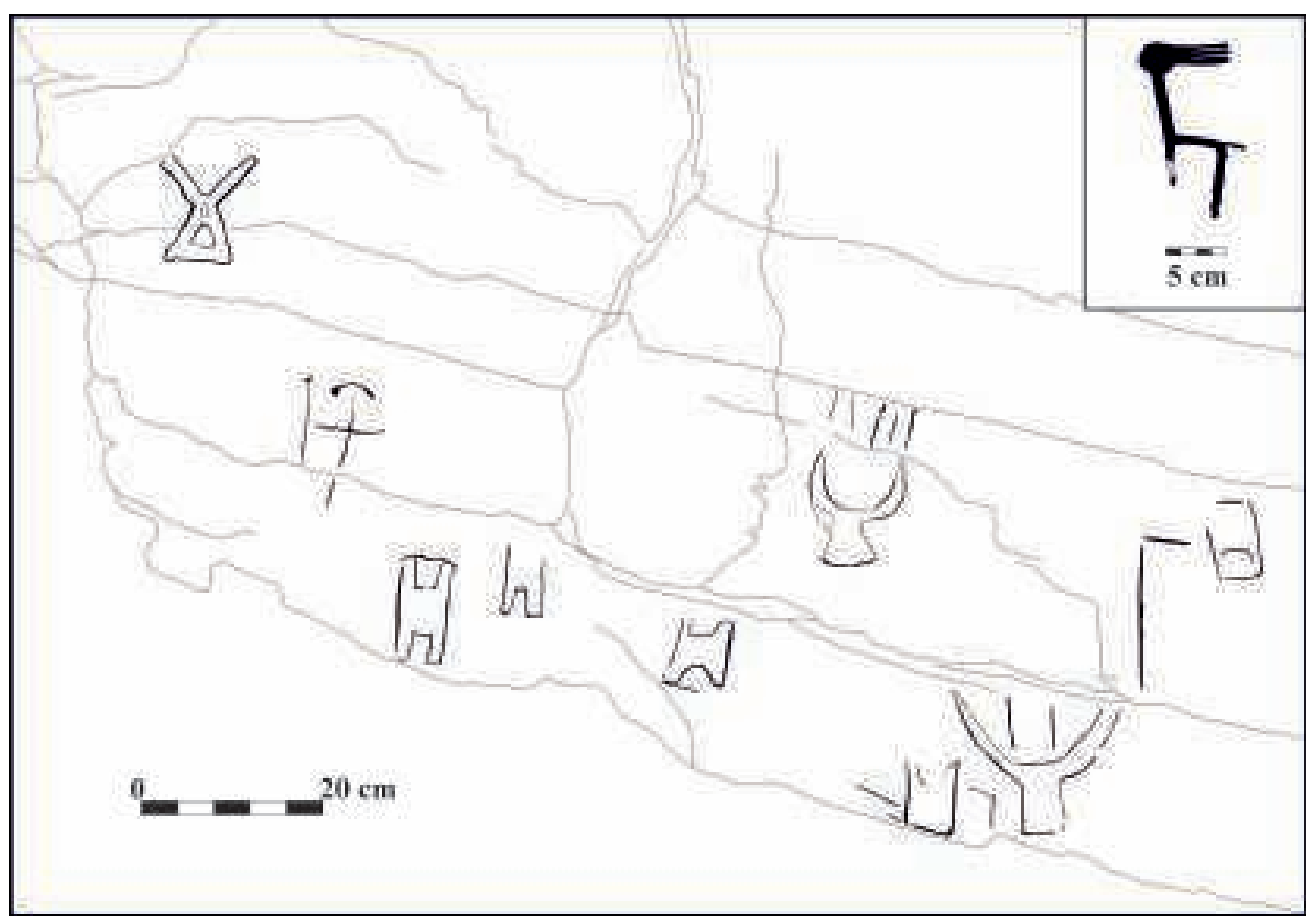

Figura 8. Grabados del Alero del Fundición.

Si bien podemos adscribir cronológicamente las producciones visuales rupestres de Calilegua, sobre una base comparativa con regiones vecinas, a los períodos de Desarrollos Regionales e Inka, resulta difícil cernir con precisión el contexto social y político que las enmarca. Así, la extensa distribución geográfica de los diseños escutiformes u de hombreshachas fue considerada tanto como una de las evidencias de las interacciones regionales que mantuvieron las sociedades tardías (Tarragó et al., 1997, Aschero, 2000, Hernández Llosa, 2001a y b), como un indicador de las relocalizaciones poblacionales (mitmackunas) implementados por los inkas en regiones como el norte de Chile (Tarragó et al., op. cit.). Más evidentes resultan las imágenes antropomorfas con atuendos rectangulares decorados muchas veces representaciones de hombres portando unkus-, las cuales fueron relacionadas con la expansión meridional de los inkas (Berenguer, 1999, 2004a). Asimismo, consideramos que los diseños ancoriformes, trátese de representaciones de diademas, pectorales o bancos de autoridades, formaron igualmente parte de un conjunto de imágenes relacionadas con los emblemas de poder difundidas durante este último período. Las imágenes rupestres, coherentes de manera general con la carta arqueológica de la región, sugiere estos tres contextos planteados: la interacción de sociedades regionales, la presencia de mitmackunas, y la difusión ideológica que acompañó la expansión de los inkas. Si bien se trata de contextos específicos y diferenciados, no son por lo tanto exclusivos ni contradictorios; incluso ellos pudieron haberse presentado simultáneamente durante las décadas en que el territorio estuvo sometido a los inkas. En este sentido, podemos constatar una cierta correspondencia con las informaciones históricas señaladas al principio de este trabajo, en tanto que éstas se refieren tanto a la presencia de mitmackunas establecidos por los inkas -lo cual conlleva una posesión 
territorial-, como al sometimiento de la población local, los ocloyas, a sus vecinos quebradeños: los omaguacas.

\section{Comentarios}

En la historiografía, la serranía de Calilegua fue generalmente presentada como un espacio de frontera vinculado directamente con la Quebrada de Humahuaca cuando no asociada con un "indiferenciado" universo cultural de las tierras bajas chaqueñas (Cruz, 2010b). Los nuevos datos arqueológicos, aunque incipientes, señalan un rol más preponderante de la región dentro de las dinámicas y procesos sociales que caracterizaron los Desarrollos Regionales, y más particularmente durante el período Inka. El registro de explotaciones mineras prehispánicas en el cerro Fundición, así como la disponibilidad y variedad de recursos simbólicos, como los vegetales enteógenos, especies de coca silvestres, pieles, plumas, y muy probablemente cultivos de coca, sugieren una imagen de la región durante este último período cercana a los conceptos de hinterland y outer- hinterland (Cruz, 2010a); un espacio tanto de aprovisionamiento como de interacciones sociales en una escala regional y extraregional. Es en razón de la multiplicidad de recursos económicos existentes en el área que se explica, en efecto, el interés volcado en ella por la empresa colonial del Tawantinsuyu en su expansión meridional. Aparte de los aspectos meramente económicos, aunque imbricados ciertamente con estos, se destaca particularmente en la serranía una cierta voluntad de apropiación simbólica del espacio y construcción territorial por parte de los inkas, puesta en evidencia tanto en el establecimiento de los santuarios de altura, la red de caminos y en el arte rupestre.

Este agenciamiento de los recursos materiales y simbólicos, los cuales aparte de estructurar las condiciones prácticas de la existencia social otorgaron una determinada identidad territorial, involucraría al conjunto de pisos ecológicos presentes en la estrecha franja de Yungas. Y es desde la serranía de Calilegua donde se domina visualmente, por encima de las nubes, la integralidad del territorio, y más allá de éste: el piedemonte y llanura chaqueña por el este, la cuenca del río Valle Grande y los estrechos valles que anteceden la Quebrada de Humahuaca por el oeste. Este dominio visual se expresa particularmente en la localización extrema de las plataformas del cerro Amarillo, todas ellas dispuestas sobre el borde de un abrupto y profundo precipicio, frente a densas y homogéneas masas nubosas que se abren por momentos hacia un profundo horizonte verde. En esta misma perspectiva territorial y geo-simbólica (Bonnemaison, 1992: 76), se enmarcan los sitios con arte rupestre recientemente registrados, todos ellos localizados en espacios de comunicación con otros pisos ecológicos y asociados con antiguas vías circulación, que presentan segmentos calzados de piedras, características que los acercan a los punkus (portales) andinos prehispánicos (Cruz, 2006), los cuales fueron particularmente celebrados por los inkas. Las imágenes rupestres que se encuentran en estos sitios, en tanto que unidades significantes, con múltiples sentidos y correlaciones (sensu Barthes, 1971:12), sobrepasan sus aspectos formales e interpretaciones inmediatas. Así, las figuras de hombres portando atuendos rectangulares (unkus) y otros atributos particulares (tocados, banderines), así como los grabados que podrían estar representando emblemas de prestigio como fueron las diademas o bancos de autoridades, sugieren la intervención de estos diseños en la marcación simbólica tanto de una jurisdicción territorial como del poder político ${ }^{11}$ (Monnet, 2000; Veschambre, 2004), aspectos coherentes con la estructura centralizada del Tawantinsuyu. En este sentido, y al menos en el contexto del arte rupestre de este período, se trata de imágenes "salientes" (sensu "saillance") tanto 
desde el punto de vista físico, como cognitivo y semántico; imágenes-agentes que sobresalen y cautivan la atención dada su pregnancia ${ }^{12}$ y su(s) sentido(s).

Al respecto, tanto Ruiz (2002) como Berenguer (2009), quienes exploraron las acepciones del vocablo unku, comúnmente utilizado para identificar las camisetas inkaicas, señalaron el rol que tuvieron estas representaciones en tanto que imágenes de poder, además de distintivo étnico o cultural. Retomando las definiciones de Bertonio (1984[1612]), Berenguer subrayó la posible relación semántica existente entre los vocablos unku y punku ${ }^{13}$; vínculo que se muestra más explícito en las representaciones rupestres de atuendos registradas en varios otros antiguos punkus del área surandina que estuvieron bajo el dominio territorial del Inka.

A semejanza de lo observado en otros punkus del espacio surandino, los sitios con arte rupestre de la serranía de Calilegua continuaron funcionando durante el período de contacto en tanto que hitos territoriales y soportes expresivos, reflejando en sus paredes continuidades y discontinuidades religiosas, así como las transformaciones culturales y sociales que tuvieron lugar por entonces. La presencia de cruces cristianas, imágenes igualmente "salientes" y de fuerte eficacidad simbólica, es un testimonio explícito de la instauración del poder colonial, de la extirpación de los antiguos cultos y de la adopción/imposición de nuevos símbolos religiosos. La representación de un cura armado de una cruz en el sitio Duraznillo, representación conocida en otras regiones andinas (Martínez, 2009), da cuenta del fuerte impacto que tuvieron entre la población estos nuevos actores del orden colonial; su figuración en un antiguo lugar de culto es en cierta manera una manifestación de resistencia frente a este nuevo orden. Asimismo, las imágenes de seres híbridos (hombres con cabeza de pájaro)y las prácticas narrativas y rituales asociadas con éstas, se insertarían dentro de este mismo marco de resistencia -y de memoria-, que tuvo lugar durante los primeros momentos de la Colonia. Otras composiciones señalan la incorporación de nuevos elementos dentro de temáticas pre-existentes y de larga duración. Tal es el caso de las representaciones de caballos y jinetes montados de pie sobre caballos, las cuales se muestran, más allá de la fascinación que pudo haber provocado este animal, en continuidad con las representaciones prehispánicas de hombres montados sobre llamas (Gallardo et al., 1990).

Después de este período de contacto, y muy probablemente como resultado de las relocalizaciones poblacionales que tuvieron lugar en torno a las reducciones y de la acción evangelizadora, los sitios con arte rupestre de la serranía cayeron en un prolongado vacío de personas y de nuevas imágenes. No sería hasta varios siglos después, en épocas republicanas y subactuales, que estos sitios volvieron a sumar nuevas diseños, en los que sobresalen las representaciones naturalistas de animales domésticos como los bueyes, los caballos y algunas aves, a la par de palabras entrecortadas y algunas fechas.

\section{Agradecimientos}

Agradecemos a Marcelo Fernández, Intendente del Parque Nacional Calilegua, a Marcelo Llanos, Intendente del Municipio Libertador Gral. San Martín por el apoyo logístico brindado y al equipo del Programa de Arqueología del Parque Nacional Calilegua por su compromiso y desempeño. Agradecemos también a José Berenguer, Matthias Strecker y Axel Nielsen por sus valiosos comentarios y observaciones. Finalmente, agradecemos a los dos evaluadores anónimos que contribuyeron notablemente con sus observaciones y sugerencias. Las opiniones aquí vertidas son de nuestra responsabilidad.

Notas

${ }^{1}$ Entre otros: Juan Ochoa de Zárate en 1596 (ver Sánchez y Sica, 1990) y Sotelo de Narvaéz (1965 [1552]). 
${ }^{2}$ Ver también: Tommasini (1933: 41-6) y Sánchez y Sica (1990:471).

${ }^{3}$ Entre otros: Nielsen, 1989; Cremonte y Garay de Fumagalli, 1995, 1997; De Feo y Fernández, 1998).

${ }^{4}$ Tal como lo señalan un gran número de fuentes documentales de comienzos de la colonia -informaciones corroboradas desde la arqueología-, la valoración simbólica de estos recursos en los Andes es dada tanto por su uso religioso y ritual como en la elaboración de ornamentaciones y bienes de prestigio.

${ }^{5}$ La definición de santuario de altura es dada tanto por la presencia de plataformas y recintos rectangulares -morfológicamente similares a los observados en otros santuarios de altura conocidos-, como por la localización sobre las cumbres y su cercanía a un establecimientos inkaico (en este caso Pueblito). Es importante señalar que, a pesar de su distintivo, la presencia de estos santuarios no es exclusiva de las altas cumbres andinas, ellos fueron igualmente construidos en cerros y montañas de baja y mediana altitud (p.e. cerro Esmeralda, Iquique, $905 \mathrm{msnm})$.

${ }^{6}$ Es importante señalar que la discriminación entre senderos y caminos no es siempre evidente. Un mismo trayecto puede comportar segmentos de un ancho variable entre $1 \mathrm{~m} \mathrm{y} 4 \mathrm{~m}$.

${ }^{7}$ De origen templario y correspondiente a los primeros momentos de la colonia, se trata de una cruz rematada en sus extremos por crucetas perpendiculares, las cuales representan los cuatro puntos cardinales.

${ }^{8}$ Uno de los evaluadores de este trabajo sugirió que estos diseños podrían tratarse de representaciones de bancos de autoridades, tianas entre los inkas, objetos que sabemos tuvieron una gran importancia simbólica en numerosas sociedades andinas prehispánicas y coloniales (Martínez Cereceda, 1995). Consideramos esta observación muy sugestiva no sólo por las semejanzas formales con los diseños rupestres en cuestión, sino también con las representaciones de otros emblemas de poder en los Andes como fueron las diademas y los pectorales. Y en efecto, los diseños ancoriformes del sitio Tambores- 2 fueron interpretados tanto como representaciones de "bancos de kurakas" como "pectorales" (Núñez et al., Ibid). ${ }^{9}$ Guaman Poma de Ayala, 1989 [1615]; Murúa 2004[1590].

${ }^{10}$ En una aproximación más ajustada, y dada sus semejanzas formales con hachas líticas y metálicas tardías, estos diseños fueron interpretados como hachas personificadas u hombreshachas (Aschero, 2000:33; Pimentel, 2006:45; Pimentel y Montt, 2009).

11 "La dimensión simbólica relaciona entre ellas las otras dimensiones de la centralidad; ella permite que el valor y sentido acordado a un lugar y a su planificación se inserten dentro del sistema social de valores y significaciones. La dimensión simbólica permite comprender, reconocer y producir la centralidad en un juego en que todos los actores geográficos no son iguales"(Monnet, 2000: 416).

${ }^{12}$ Tanto en el sentido de la Gestalt como el de Thom (1988). La pregnancia se mide en la intensidad de la fuerza atractiva/repulsiva que las imágenes provocan en el sujeto que las observa. Las formas llenas y geométricas, las líneas rectas y los vértices poseen una mayor pregnancia visual.

${ }^{13}$ Uncu: la mantellina, o tocado de las indias. / uncusutha: sacar./ uncuntartha: meter (:377).

Ponco.l.quillca: la puerta por donde se entra a alguna parte (:273).

\section{Bibliografía citada}

Adris, $\mathrm{S}$.

2007. Arte, aguadas, tropas y sembradíos. Actas del XVI Congreso Nacional de Arqueología Argentina, T. II: 407-419, San Salvador de Jujuy. 
Aschero, C.

2000. Figuras humanas, camélidos y espacios en la interacción circumpuneña. En: Arte en las rocas. Arte rupestre, menhires y piedras de colores en Argentina, M. Podestá y M. de Hoyos (Eds):15-44, Sociedad Argentina de Antropología, Buenos Aires.

Barthes, R.

1971. L'aventure sémiologique. Points Seuil, París.

Berenguer, J.

2009. Arte rupestre inkaico en el sur del Imperio, o la estrecha camixeta de la nueva servidumbre. Comunicación presentada en el TANOA II, Las tierras altas del área CentroSur andina entre el 1000 y el 1600 d.C., CREA-Universidad Nacional de Jujuy, San Salvador de Jujuy.

2004a. Cinco milenios de arte rupestre en los Andes atacameños: imágenes para lo humano, imágenes para lo divino. Boletín del Museo Chileno de Arte Precolombino No 9: 75-108, Santiago. 2004b. Caravanas, interacción y cambio en el desierto de Atacama. Sirawi Ediciones. Santiago 1999. El evanescente lenguaje del arte rupestre en los Andes atacameños. En: Arte rupestre en los Andes de Capricornio, Berenguer, J. y F. Gallardo (Eds) : 9-56. Museo Chileno de Arte Precolombino / Banco Santiago, Santiago.

Bertonio, L.

1984 [1612]. Vocabulario de lengua aymara. Ceres, La Paz.

Boman, E.

1908. Antiquités de la Région Andine de la République Argentine et du Désert d'Atacama. T. II, Imprimerie Nationale, París.

Bonnemaison, J.

1992. Le territoire enchanté. Croyances et territorialités en Mélanésie. Géographie et culture $\mathrm{N}^{\circ}$ $3: 72-88$, Laboratoire Espace et Culture, París.

Brown, A. y M. Kapelle.

2001. Introducción a los bosques nublados del geotrópico: una síntesis regional. En: Bosques Nublados del Neotrópico, M. Kappelle y A.D. Brown (Eds.) : 25-38, Editorial INBio. S. D. de Heredia, Costa Rica.

Cabrera, A.

1976. Regiones fitogeográficas de la República Argentina. Enciclopedia de Agricultura, Jardinería y Fruticultura, 2: 1-85, ACME, Buenos Aires.

Canals Frau, S.

1953. Las poblaciones Indígenas de la Argentina. Su origen-su pasado- su presente. Sudamericana, Buenos Aires.

Cremonte, M. B.

2006. El estudio de las cerámicas en la reconstrucción de las historias locales. El sur de la Quebrada de Humahuaca (Jujuy, Argentina) durante los Desarrollos Regionales e Incaico. Chungara Vol. 38 N $^{\circ}$ 2: 239-247, Arica. 
Cremonte, M. B. y M. Garay de Fumagalli

1995 Estado actual de las investigaciones arqueológicas en el sector meridional de la Quebrada de Humahuaca y su borde oriental. En: Actas I Congreso en Investigación en Ciencias Sociales : 379-393, Universidad Nacional de Tucumán, Tucumán.

1997 El enclave de Volcán en las vinculaciones transversales del Valle de Humahuaca (Noroeste de Argentina, Jujuy). En: Intercambio y Comercio entre Costa, Andes y Selva. Arqueología y Etnohistoria de Sudamérica, F. Cárdenas-Arroyo y T. Bray (Eds.): 297-319, Universidad de Los Andes, Bogotá.

Cruz, P.

2006. Mundos permeables y espacios peligrosos. Consideraciones acerca de punkus y qaqas en el paisaje altoandino de Potosí, Bolivia. Boletín del Museo Chileno de Arte Precolombino Vol. $11 \mathrm{~N}^{\circ}$ 2:35-50, Santiago.

2010a. Monte adentro. Aproximaciones sobre la ocupación prehispánica de la Serranía de Calilegua, II ${ }^{\mathrm{do}}$ milenio d.C. Intersecciones en Antropología $\mathrm{N}^{\circ}$ 11: 129-144, UNCPBA, Olavarría. 2010b. Del Ande a los Andes. Reflexiones comparativas en torno a los procesos de complejización social desde la región Valliserrana (Noroeste argentino). En: Andes, Amazonas y sus transformaciones. Comparaciones, conexiones, fronteras entre las tierras altas y bajas de Sud América . Platt T., G. Rivière e I. Daillant. (Eds.). University of St. Andrews, St. Andrews. En prensa.

Debarbieux, B.

1999. Le territoire : Histoires en deux langues. En: Discours scientifique et contextes culturels. Géographies françaises à l'épreuve postmoderne, Chivallon C. (Ed.) : 33-46. Maison des Sciences de l'homme d'Aquitaine, Bordeaux.

De Feo, C. y A. Fernández.

1998. Una aproximación al Período Tardío en la arqueología de Valle Grande (Jujuy). En: Pasado y presente de un mundo postergado estudios de antropología, historia y arqueología del Chaco y Pedemonte Surandino, Teruel, A. y O. Jerez (Comp.): 341-361. Universidad Nacional de Jujuy, San Salvador de Jujuy.

Di Méo, G.

1991. L'homme, la société, l'espace. Anthropos-Economica, París.

Dougherty, B.

1977. Análisis de la variación cerámica en el Complejo San Francisco. Obra del Centenario del Museo de La Plata T. II: 237-252, Universidad Nacional de La Plata, La Plata.

1974. Informe preliminar sobre un nuevo yacimiento arqueológico en Palpalá, Provincia de Jujuy, su ubicación dentro del Complejo San Francisco. Relaciones de la Sociedad Argentina de Antropología T. VIII: 135-152, Buenos Aires.

Fernández Cornejo, J. A.

1837. Diario de la Primera Expedición al Chaco emprendida en 1780. En: de Angelis, P., Colección de obras y documentos relativos a la Historia Antigua y Moderna de las provincias del Río de La Plata, tomo sexto, Imprenta del Estado, Buenos Aires. 
Fernández Distel, A.

1988. La cueva con pictografías de San Lucas, Depto. Valle Grande, Jujuy (Argentina). Informe Preliminar. Boletín SIARB No 2: 53-60, La Paz.

1992. Pinturas rupestres posteriores a la conquista española en Jujuy, San Lucas, Dep. Valle Grande, Argentina. En: Arte Rupestre Colonial de Bolivia y Países Vecinos, Querejazu Lewis, R. (Ed.) : 199-209. Contribuciones al Estudio del Arte Rupestre Sudamericano, SIARB, La Paz. 2004. Iconografía prehispánica de Jujuy: una visión desde la arqueología. Editorial Dunken, Buenos Aires.

Gallardo, F., V. Castro y P. Miranda.

1990. Jinetes sagrados en el desierto de Atacama: Un estudio de arte rupestre andino. Boletín del Museo Chileno de Arte Precolombino No4: 27-56, Santiago.

Gell, A.

1998. Art and Agency: An Anthropological Theory. Clarendon, Oxford.

Guaman Poma de Ayala, F.

1989 [1615]. Nueva coronica y buen gobierno. Institut d'Ethnologie, edición facsimilar, París.

Hernández Llosas, M. I.

2001a. Arte rupestre del Noroeste argentino. Orígenes y contextos de producción. En: Historia Argentina prehispánica, I. Berberián, E. y A. Nielsen (Eds): 389-446, Editorial Brujas, Córdoba. 2001b. Tres momentos, tres contextos, un lugar: Variaciones temporales y contextuales en el arte rupestre de la Quebrada de Humahuaca, Jujuy, Argentina. Boletín Museo Chileno de Arte Precolombino $\mathrm{N}^{\circ}$ 8: 59-82, Santiago.

1992. Secuencia Rupestre Humahuaca y Arqueología Regional (Jujuy, Argentina). Boletín SIARB 6 : 29-40, La Paz.

INTA-Salta.

2004. Aptitud ecológica para el cultivo de coca (Erythroxylum sp.) en el NOA. Boletín Desideratum Año II - No 19, Estación Experimental Agropecuaria, Salta.

Kulemeyer, J. y M. Echenique.

2002. Yacimiento de Moralito, San Pedro de Jujuy, Provincia de Jujuy (Argentina). Pacarina Año II N 2: 51-62, San Salvador de Jujuy.

Kulemeyer, J., M. Echenique y L. Laguna.

1997. La cerámica con decoración incisa y modelada de Bajo La Viña, San Salvador de Jujuy (Argentina). Cuadernos 9:87-110, FHyCS, Universidad Nacional de Jujuy, San Salvador de Jujuy.

Lefebvre, $\mathrm{H}$.

1981. La production de l'espace. Editions Antrophos, París.

1976. Espacio y política. Ediciones Península, Barcelona.

Lorandi, A. M.

1980. La frontera oriental del Tawantinsuyu: el Umasuyu y el Tucumán. Una hipótesis de trabajo. Relaciones, nueva serie, T. XIV: 147-164, Buenos Aires. 
Martínez, J.L.

2009. Registros andinos al margen de la escritura: el arte rupestre colonial. Boletín del Museo Chileno de Arte Precolombino Vol.14, No.1: 9-35, Santiago.

1995. Autoridades en los Andes, los atributos del Señor. Pontificia Universidad Católica del Perú. Lima.

Monnet, J.

2000. Les dimensions symboliques de la centralité. Cahiers de Géographie du Québec Vol. 44, N¹23: 399-418, Québec.

Murúa, M. de.

2004[1590]. Juan Ossio. Códice Murúa: Historia y Genealogía de los Reyes Incas del Perú del Padre Mercenario Fray Martín de Murúa: Códice Galvin. Testimonio Compañía Editorial, Madrid, facsímil.

Nielsen, A.

1989. La ocupación indígena del territorio Humahuaca oriental durante los períodos de Desarrollos Regionales e Inca. Tesis doctoral inédita. Universidad Nacional de Córdoba, Córdoba.

1997. Tiempo y cultura material en la quebrada de Humahuaca (700-1650 d.C). Instituto Interdisciplinario Tilcara (FFyL- UBA). Tilcara.

Nielsen, A., M., Vazquez, P., Mercolli y V., Seldes.

2001. Las Pictografias de Kollpayoc (Departamento Humahuaca, Jujuy, Argentina). En: Arte Rupestre y Región. Arte Rupestre y Menhires en el Sur de Bolivia, Norte de Argentina y Norte de Chile, Fernández Distel, A. (Ed.): 91-108, Anuario del Centro de Estudios Indígenas y Coloniales, Universidad Nacional de Jujuy, San Salvador de Jujuy.

Núñez, L., I. Cartajena, J. Loo, S. Ramos, Ti. Cruz, To. Cruz y H. Ramírez. 1997. Registro e investigación del arte rupestre en la Cuenca de Atacama (informe preliminar). Estudios Atacameños No 14: 307-326, San Pedro de Atacama.

Ortiz, G.

2002. Nuevos avances en torno a las investigaciones arqueológicas en las tierras bajas de Jujuy (subárea San Francisco). Pacarina, Año II N²: 73-91, San Salvador de Jujuy.

2000 Estado actual del conocimiento acerca del denominado Complejo o tradición cultural San Francisco a 100 años de su descubrimiento. En: La mitad verde del mundo andino. Investigaciones arqueológicas en la vertiente oriental de los Andes y las tierras bajas de Bolivia y Argentina, Ortiz G. y Ventura B. (Eds.): 23-721, FHyCS, Universidad Nacional de Jujuy, San Salvador de Jujuy.

1998 Del olvido al protagonismo. En: Repensando la arqueología de las tierras bajas jujeñas. Pasado y presente de un mundo postergado. Teruel, A. y O. Jerez (Comp.) Estudios de arqueología, historia y antropología sobre el Chaco y el pedemonte surandino. Universidad Nacional de Jujuy. San Salvador de Jujuy.

Pimentel, G.

2006. Evidencias regionales en rutas interregionales prehispánicas que conectaron con San Pedro de Atacama. En: Arte Americano: contextos y formas de ver, Terceras Jornadas de Historia del Arte. Martínez Silva, J.M. (Ed.): 41-48, RIL Editores, Santiago. 
Pimentel, G. e I. Montt.

2009. Grabados Antropomorfos Tardíos. El caso de las Personificaciones de Hachas en San Pedro de Atacama (Norte de Chile). En: Crónicas sobre la Piedra. Arte Rupestre de las Américas, Sepúlveda, M., L, Briones y J. Chacama (Eds.): 221-234, Ediciones Universidad de Tarapacá, Arica.

2008.Tarapacá en Atacama. Arte rupestre e interacciones societales entre el 900 y 1450 DC. Boletín Museo Chileno de Arte Precolombino Vol. 13, No 1:35-50, Santiago.

Raffestin, C.

1986. Ecogenèse territoriale et territorialité. Espaces, jeux et enjeux, Auriac, F. y R. Brunet (Eds) : 173-185, Fayard, París.

Raffino, R.

1993. Inka. Arqueología, historia y urbanismo del altiplano andino. Ediciones Corregidor. Buenos Aires.

Ruiz, M.

2002. Unkus, caminos y encuentros. Revista Andina No 34: 199-215, Centro Estudios Regionales Bartolomé de las Casas, Cuzco.

2005. Unkus en la Puna de Jujuy. En: Jujuy, arqueología, historia, economía y sociedad, Santamaría, D. (Ed.) : 82-95, CEIC, Universidad Nacional de Jujuy, San Salvador de Jujuy.

Ruiz, M., M. Albeck y D. Chorolque.

2001. Conflicto y memoria. Arte rupestre de las Tierras Altas de Jujuy. Siglos XII al XV. En: Arte Rupestre y Región. Arte Rupestre y Menhires en el Sur de Bolivia, Norte de Argentina y Norte de Chile, Fernández Distel, A. (Ed.): 81-90, Anuario del Centro de Estudios Indígenas y Coloniales, Universidad Nacional de Jujuy, San Salvador de Jujuy.

Sánchez, S. y G. Sica.

1990. La Frontera Oriental de Humahuaca y sus Relaciones con el Chaco. Bulletin de l'Institut Français d'Etudes Andines 19, Nº 2: 469-497, Lima.

Sotelo de Narváez, P.

1965 [1552]. Relación de las Provincias de Tucumán que Dio Pedro Sotelo Narváez, Vecino de Aquellas Provincias, al muy Illustre Señor Licenciado Cepeda, Presidente desta Real Audiencia de la Plata. RGI, Biblioteca de Autores Españoles, Vol. 183: 390-401, Madrid

Soja, E.

1971. The political organization of space. Association of American Geographers, Washington. Tarragó, Mi, L. González y J. Nastri.

1997. Las interacciones prehispánicas a través del estilo: el caso de la iconografía santamariana. Estudios Atacameños No14: 223-242, San Pedro de Atacama.

Thom, R. 1988. Esquisse d'une sémiophysique. InterÉditions, París.

Tommasini, C.

1933. Los indios ocloyas y sus doctrineros en el siglo XVII. Imprenta de la Universidad, Córdoba. 
Ventura, B.

2007. Proceso de ocupación humana de la Finca San Andrés. En: Finca San Andrés. Un espacio de cambios ambientales y sociales en el Alto bermejo, Brown, M., M. García, B. Ventura, N. Hilgert y L. Malizia (Eds.): 101-127, Ediciones del Subtrópico, Tucumán.

Veschambre, V.

2004. Appropriation et marquage symbolique de l'espace : quelques éléments de réflexion. Travaux et documents de l'UMR ESO 6590 CNRS, N²21 : 73-77, Nantes.

Vergara, M. A.

1966. Compendio de la historia de Jujuy. Imprenta de la Provincia, San Salvador de Jujuy. 